\title{
Proteomic Studies of Syk-Interacting Proteins Using a Novel Amine-Specific Isotope Tag and GFP Nanotrap
}

\author{
Jacob A. Galan, ${ }^{1}$ Leela L. Paris, ${ }^{2}$ Hua-jie Zhang, ${ }^{1}$ Jacob Adler, ${ }^{1}$ Robert L. Geahlen, ${ }^{2,4}$ \\ W. Andy Tao ${ }^{1,2,3,4}$ \\ ${ }^{1}$ Department of Biochemistry, Purdue University, West Lafayette, IN 47907, USA \\ ${ }^{2}$ Department of Medicinal Chemistry and Molecular Pharmacology, Purdue University, West Lafayette, IN USA \\ ${ }^{3}$ Department of Chemistry, Purdue University, West Lafayette, IN USA \\ ${ }^{4}$ Purdue University Center for Cancer Research, West Lafayette, IN USA
}

\begin{abstract}
Green fluorescent protein (GFP) and variants have become powerful tools to study protein localization, interactions, and dynamics. We present here a mass spectrometry-based proteomics strategy to examine protein-protein interactions using anti-GFP single-chain antibody $\mathrm{V}_{\mathrm{H}} \mathrm{H}$ in a combination with a novel stable isotopic labeling reagent, isotope tag on amino groups (iTAG). We demonstrate that the single-chain $V_{H} H$ (GFP nanotrap) allows us to identify interacting partners of the Syk protein-tyrosine kinase bearing a GFP epitope tag with high efficiency and high specificity. Interacting proteins identified include CrkL, BLNK, $\alpha$ - and $\beta$ tubulin, Csk, RanBP5 and DJ-1. The iTAG reagents were prepared with simple procedures and characterized with high accuracy in the determination of peptides in model peptide mixtures and as well as in complex mixture. Applications of the iTAG method and GFP nanotrap to an analysis of the nucleocytoplasmic trafficking of Syk led to the identification of location-specific associations between Syk and multiple proteins. While the results reveal that the new quantitative proteomic strategy is generally applicable to integrate protein interaction data with subcellular localization, extra caution should be taken in evaluating the results obtained by such affinity purification strategies as many interactions appear to occur following cell lysis.
\end{abstract}

Key words: Green fluorescent protein, Single-chain antibody, Isotopic labeling, Nucleocytoplasmic trafficking, Spleen tyrosine kinase, Protein-protein interaction

\section{Introduction}

$\mathrm{M}$ ass spectrometry has become a powerful tool to identify protein-protein interaction networks by cou-

\footnotetext{
Electronic supplementary material The online version of this article (doi:10.1007/s13361-010-0030-7) contains supplementary material, which is available to authorized users.
}

Correspondence to: W. Andy Tao; e-mail: watao@purdue.edu pling with immunoaffinity purification [1]. A common practice is the preparation and expression of a "bait" protein bearing single epitope tag or multiple tags (e.g., tandem purification tag). The use of epitope tags increases the efficiency of identifying protein interacting partners and bypasses the problem of limited availability of specific antibodies for many bait proteins [2-4]. Among common epitope tags, green fluorescent protein (GFP) and variants are extremely appealing since they are widely used to determine protein location and dynamics in living cells. 
However, until lately, the use of GFP as an epitope tag for immunoaffinity purification-mass spectrometry (IP-MS) has been limited due to the inconsistent quality of anti-GFP antibodies and the interference of antibody heavy and light chains in IP-MS analyses. Recently, Rothbauer et al. engineered a variable single domain antibody fragment, $\mathrm{V}_{\mathrm{H}} \mathrm{H}$, which is highly specific for fluorescent proteins $[5,6]$. The GFP-binding $\mathrm{V}_{\mathrm{H}} \mathrm{H}$ is small $(2.4 \times 4.5 \mathrm{~nm}$; molecular mass $13 \mathrm{kDa}$ ) and can be produced easily in Escherichia coli. This "GFP nanotrap" provides a robust and highly efficient tool for the isolation of GFP fusion proteins and, consequently, the analysis of their interacting partners [7].

Quantitative proteomics based on stable isotope labeling combined with IP-MS has been used by many groups to characterize protein complexes [8-10]. Common stable isotope labeling approaches include metabolic (e.g., SILAC [11]) or chemical (e.g., ICAT [12] or iTRAQ [13]) labeling. The main advantage of metabolic labeling such as SILAC is the early incorporation of the isotope label which minimizes the number of manipulations, thus allowing for the least amount of variation between the samples during the preparative procedures. Metabolic labeling, however, is typically expensive, does not applicable to clinical samples, and complete incorporation of labeled amino acids needs to be optimized for individual cell types. On the other hand, because of the numerous labeling molecules and a variety of chemistry that can be utilized to tag different positions on a protein or peptide, chemical labeling provides researchers with many choices with the manner of selectively introducing an isotope tag by chemical reactions onto a desired site on a peptide or protein. Here, we introduce a new aminespecific reagent, which we term isotope Tag on Amine Groups (iTAG), for chemical incorporation of a stable isotope coded tag on tryptic peptides for their quantification and identification by MS. We demonstrate that the new iTAG reagents have minimal effects on both the ionization efficiency and fragmentation pattern of the labeled peptides. More importantly, the reagents, including the heavy isotope version, are prepared by extremely simple and economic procedures and can be adapted to any biological or proteomic research group for stable isotope incorporation.

Here we report a new application of GFP nanotrap and iTAG for the isolation of tyrosine kinase Syk-interacting partners in chicken DT40 B cells. The model system was particularly used to examine the feasibility of subcellular location-dependent protein-protein interactions. Spleen tyrosine kinase (Syk) is a $72-\mathrm{kDa}$ protein tyrosine kinase with an $\mathrm{N}$-terminal tandem pair of $\mathrm{SH} 2$ domains separated by a long linker (linker B) from a C-terminal catalytic domain. Syk is known to have a crucial role in adaptive immune receptor signaling, in particular in B cells by coupling the B-cell receptor (BCR) for antigen to multiple intracellular signaling pathways, and also in modulating cellular responses to inducers of oxidative stress in a receptor-independent fashion [14]. In B cells, Syk is found in both the nuclear and cytoplasmic compartments, but contains no traditionally recognizable nuclear localization or export signals [15]. Engagement of the BCR recruits Syk from both the cytoplasm and nucleus to the aggregated BCR complex. Following receptor internalization, Syk returns quickly to both compartments, but is then excluded from the nucleus at longer time points following BCR engagement in a process that requires the activation of protein kinase $\mathrm{C}$ and new protein synthesis [16]. However, much remains to be determined in identifying what Syk-interacting partners are present in different subcellular compartments.

To facilitate out study, we used two stably transfected cell lines expressing Syk-EGFP with restricted subcellular locations: Syk-EGFP-NLS, a fusion protein bearing a nuclear localization sequence (NLS) that is restricted to the nucleus; and Syk-EGFPNES, a fusion protein bearing a nuclear export sequence that is present only in the cytoplasm. Syk-interacting partners were isolated with GFP nanotrap from each cell type and the iTAG technology was used to quantify differences in specific binding partners from different subcellular locations. Analyses of multiple proteins quantified in Syk-EGFP-NLS and Syk-EGFP-NES complexes showed that the combined approaches allow the identification of specific interaction partners. However, the results also indicate that the approach can introduce falsepositives due to interactions that arise most likely during the mixing of cellular components following cell lysis.

\section{Experimental}

\section{Cells and Cell Culture}

Syk-deficient DT40 B cell lines expressing Syk-EGFP, SykEGFP-NES, or Syk-EGFP-NLS were generated and cultured as described previously [16-18]. Cells were maintained at a density of $0.2-0.8 \times 10^{6}$ cells $/ \mathrm{mL}$ in RPMI 1640 supplemented with $8 \%$ fetal calf serum, $1 \%$ chicken serum, $50 \mu \mathrm{M}$ 2-mercaptoethanol, $1 \mathrm{mM}$ sodium pyruvate, $100 \mathrm{IU} / \mathrm{mL}$ penicillin $\mathrm{G}$, and $100 \mu \mathrm{g} / \mathrm{mLl}$ streptomycin. Equivalent expression of Syk-EGFP, Syk-EGFP-NLS, and Syk-EGFPNES was verified by Western blotting. The appropriate localization of each fusion protein was confirmed in cells that were adhered to poly-L-lysine-coated coverslips, fixed with $3.7 \%$ formaldehyde in PBS, stained with 4,6'-diamidino 2-phenylindole (DAPI; Sigma-Aldrich, St. Louis, MO, USA) and examined by fluorescence microscopy.

\section{Cell Fractionation}

DT40 cells expressing Syk-EGFP-NLS or Syk-EGFP-NES were grown to a density of $5 \times 10^{7}$ cells $/ \mathrm{mL}$ and harvested. Cells were resuspended in $1.5 \mathrm{~mL}$ of ice-cold buffer A (10 mM HEPES, $\mathrm{pH} 7.9,10 \mathrm{mM} \mathrm{KCl}, 0.1 \mathrm{mM}$ EDTA, $0.1 \mathrm{mM}$ EGTA, $1 \mathrm{mM}$ dithiothreitol, $1 \times$ protease inhibitor cocktail (Roche, Basel, Switzerland), and $1 \mathrm{mM}$ sodium orthovanadate), incubated on ice for $15 \mathrm{~min}$ and then vortexed for $10 \mathrm{~s}$ following the addition of NP40 to a final concentration of $0.26 \%$. The supernatant (cytosolic fraction) 
was collected by centrifugation at $1300 \times g$ for $0.5 \mathrm{~min}$. The nuclear pellet was washed twice in buffer A, resuspended in $20 \mathrm{mM}$ HEPES, $\mathrm{pH}$ 7.9, $0.4 \mathrm{M} \mathrm{NaCl}, 1 \mathrm{mM}$ EDTA, $1 \mathrm{mM}$ EGTA, $1 \mathrm{mM}$ dithiothreitol, $1 \times$ protease inhibitor cocktail, and $1 \mathrm{mM}$ sodium orthovanadate, rotated $4{ }^{\circ} \mathrm{C}$ for $15 \mathrm{~min}$ and then centrifuged at $1000 \times g$ for $5 \mathrm{~min}$. The supernatant was collected and designated as the nuclear fraction.

\section{SDS-PAGE and Western Blot Analysis}

Proteins in immune complexes (isolated using GFP nanotrap or anti-GFP antibody) were separated by SDS-PAGE, transferred onto polyvinylidene difluoride membranes, and detected by silver staining or probed with primary antibodies [anti-Syk (N-19), anti- $\gamma$ tubulin, anti- $\beta$ tubulin, anti-CrkL, anti-SP1, or anti-p38; Santa Cruz Biotechnology, Santa Cruz, CA, USA] and detected using ECL detection reagents (Amersham Biosciences, GE Healthcare, Piscataway, NJ USA).

\section{Synthesis of iTAG Reagents}

To $\gamma$-aminobutyric acid $(5.0 \mathrm{~g}, 48 \mathrm{mmol})$ was added $10 \mathrm{~mL}$ formic acid and $10 \mathrm{~mL} 37 \%$ aqueous formaldehyde. The mixture was heated at $85{ }^{\circ} \mathrm{C}$ for $24 \mathrm{~h}$. The reaction solution was cooled and solvents were dried under vacuum. Excessive concentrated $\mathrm{HCl}$ pre-cooled on ice was added and the reaction continued on ice for $1 \mathrm{~h}$. The reaction solution was dried and the product recrystalized from acetonitrile to give an NMR pure product, $\gamma$ - $(N, N$-dimethylamino)-butyric acid $(6.3 \mathrm{~g}, 78 \%) .{ }^{1} \mathrm{H}$ NMR $\left(\mathrm{D}_{2} \mathrm{O}\right.$, $300 \mathrm{MHz}): \delta 3.15(\mathrm{t}, J=8.1 \mathrm{~Hz}, 2 \mathrm{H}), 2.84(\mathrm{~s}, 6 \mathrm{H}), 2.45(\mathrm{t}$, $J=7.2 \mathrm{~Hz}, 2 \mathrm{H}), 1.93-1.98(\mathrm{~m}, 2 \mathrm{H}) . N$-trifluoroacetoxy succinimide (TFA-NHS) was prepared as reported [19]. To $\gamma$-(N,N-dimethylamino)-butyric acid $(150 \mathrm{mg}, 0.90 \mathrm{mmol})$ in THF was added di-isopropylethylamine $(313 \mu \mathrm{L}, 1.8 \mathrm{mmol})$. The mixture was stirred for $5 \mathrm{~min}$. TFA-NHS (379 $\mathrm{mg}$, $1.8 \mathrm{mmol}$ ) was added reacted at room temperature overnight, followed by centrifugation to collect insoluble material. The product was washed six times with dry THF $(3 \mathrm{~mL})$ and four times with ethyl acetate $(3 \mathrm{~mL})$. A $4 \mathrm{M}$ solution of $\mathrm{HCl}$ in dioxane $(15 \mathrm{~mL})$ was added and stirred at room temperature for $1 \mathrm{~h}$ and dried to give the final product $(167 \mathrm{mg}, 70 \%)$ as a white solid. ${ }^{1} \mathrm{H}$ NMR(DMSO, $\left.300 \mathrm{~Hz}\right): \delta 3.07(\mathrm{t}, J=$ $7.8 \mathrm{~Hz}, 2 \mathrm{H}), 2.82-2.87(\mathrm{~m}, 6 \mathrm{H}), 2.73(\mathrm{~s}, 6 \mathrm{H}), 2.03(\mathrm{t}, J=$ $7.5 \mathrm{~Hz}, 2 \mathrm{H}$ ). The heavy isotope form was synthesized in the same fashion, except formaldehyde- $\mathrm{d}_{2}$ and formic acid- $\mathrm{d}_{2}$ were used in the first step.

\section{Preparation of Labeled Peptides}

Two standard mixtures were made from four proteins (bovine serum albumin, catalase, ovalbumin, $\beta$-lactoglobulin) present at designated concentration ratios. The two mixtures were denatured in $6 \mathrm{M}$ urea, reduced with $5 \mathrm{mM}$ DTT, and incubated for $30 \mathrm{~min}$ at $37^{\circ} \mathrm{C}$. The mixtures were alkylated with $15 \mathrm{mM}$ iodoacetamide for $1 \mathrm{~h}$ at room temperature in the dark. Samples were diluted 4-fold with $20 \mathrm{mM}$ TMAB and digested with trypsin at an enzyme/ protein ratio of $1: 50$ at $37^{\circ} \mathrm{C}$ overnight or no longer than $16 \mathrm{~h}$. An aliquot $(1 \mu \mathrm{g})$ of the digested standard protein mixture was removed for labeling. Peptides derived from digests of proteins from Syk-GFP, Syk-GFP-NLS, and SykGFP-NES clones were reconstituted in $50 \mathrm{mM}$ TMAB, $\mathrm{pH}$ 8.0 , and $70 \%$ acetonitrile. Dry iTAG-d0 or iTAG-d6 reagent was added to the samples to a concentration of $100 \mathrm{mM}$ and allowed to dissolve. The $\mathrm{pH}$ was adjusted to 8.0 with $1 \mathrm{M}$ TMAB and the reaction was allowed to proceed for $1 \mathrm{~h}$ at room temperature. The reactions were quenched with $10 \mu \mathrm{L}$ of $1 \mathrm{M} \mathrm{NH}_{4} \mathrm{HCO}_{3}, \mathrm{pH} 8.0$, for $20 \mathrm{~min}$, after which the samples were combined and dried under vacuum. The samples were reconstituted in $0.1 \%$ formic acid for analysis.

\section{GFP Nanotrap and Anti-GFP Affinity Purification}

Syk-deficient DT40 cells expressing Syk-EGFP, Syk-EGFPNLS, or Syk-EGFP-NES $\left(1 \times 10^{8}\right.$ cells $/ \mathrm{mL}$ cells $)$ were lysed in $1 \mathrm{~mL}$ of ice cold $25 \mathrm{mM}$ Hepes, $\mathrm{pH} 7.4,150 \mathrm{mM} \mathrm{NaCl}, 1 \%$ NP40, $0.5 \mathrm{mM}$ EDTA, $1 \times$ protease inhibitor cocktail and $1 \mathrm{mM}$ sodium orthovanadate for $30 \mathrm{~min}$ with agitation. Cellular debris was removed by centrifugation at $13,000 \times g$ for $5 \mathrm{~min}$. The supernatant was diluted with $1 \mathrm{~mL}$ of ice cold dilution buffer containing $25 \mathrm{mM}$ Hepes, $\mathrm{pH} 7.4,150 \mathrm{mM} \mathrm{NaCl}, 0.5 \mathrm{mM}$ EDTA, $1 \times$ protease inhibitor cocktail, and $1 \mathrm{mM}$ sodium orthovanadate. Twenty $\mathrm{mL}$ (50\% slurry) of GFP nanotrap agarose resin (Chromotek, Munich, Germany) was added to the lysates and incubated for $1 \mathrm{~h}$ with end-to-end rotation at room temperature. After incubation, the GFP nanotrap was washed three times with dilution buffer and three times with $\mathrm{H}_{2} \mathrm{O}$. Proteins were eluted using $100 \mu \mathrm{L}$ of $0.2 \%$ RapiGest in $50 \mathrm{mM}$ trimethylammonium bicarbonate (TMAB), $\mathrm{pH} 8.0$, at $99^{\circ} \mathrm{C}$ for $5 \mathrm{~min}$. For isolations using anti-GFP, $10 \mu \mathrm{g}$ antibody (Santa Cruz Biotechnology) was added to the lysate and incubated for $2 \mathrm{~h}$ at $4{ }^{\circ} \mathrm{C}$. After incubation, $100 \mu \mathrm{L}$ ( $50 \%$ slurry) of protein Asepharose beads were added and incubated for $2 \mathrm{~h}$ at $4{ }^{\circ} \mathrm{C}$. After incubation, the protein A-sepharose beads were washed three times with dilution buffer and three times with $\mathrm{H}_{2} \mathrm{O}$. Proteins were eluted using $100 \mu \mathrm{L}$ of $0.2 \%$ RapiGest in $50 \mathrm{mM} \mathrm{TMAB}$, $\mathrm{pH} 8.0$ at $99^{\circ} \mathrm{C}$ for $5 \mathrm{~min}$. The isolated protein samples were reduced by addition of $5 \mathrm{mM}$ DTT for $30 \mathrm{~min}$ at $37^{\circ} \mathrm{C}$. Samples were alkylated with $15 \mathrm{mM}$ iodoacetamide for $1 \mathrm{~h}$ at room temperature in the dark. Trypsin was added to the samples at a 1:50 protease/protein ratio and incubated at $37^{\circ} \mathrm{C}$ overnight or no longer than $16 \mathrm{~h}$. RapiGest was removed by acidification with $50 \mathrm{mM} \mathrm{HCl}$ and incubation for $30 \mathrm{~min}$ at $37^{\circ} \mathrm{C}$. The peptide samples were dried under vacuum.

\section{Mass spectrometry Data Acquisition and Data Analyses}

Peptide samples in $8 \mu \mathrm{L}$ of $0.1 \%$ formic acid were introduced into an Agilent Technologies, Santa Clara, CA, USA nanoflow 1100 HPLC system. The nanoflow LC 
capillary column with integrated electrospray emitter tip was constructed in-house as described [20]. The buffer was $0.1 \%$ formic acid with an eluting buffer of $100 \% \mathrm{CH}_{3} \mathrm{CN}$ run over a shallow linear gradient (5\%-35\%) over 90 min with a flow rate of $200 \mathrm{~nL} / \mathrm{min}$. The Agilent $1100 \mathrm{HPLC}$ system was coupled online to a hybrid linear ion trap Orbitrap mass spectrometer (LTQ-Orbitrap XL; Thermo Fisher, San Jose, CA, USA). The mass spectrometer was operated in the datadependent mode in which a full scan MS was followed by MS/MS scans of the three most abundant ions excluding +1 charge state. The mass exclusion time was $180 \mathrm{~s}$. The LTQOrbitrap raw files were searched directly against Gallus gallus and Mus musculus (31,287 entries; NCBI ver. 2.1) databases using the SEQUEST algorithm [21] on the Sorcerer IDA server (Software ver. 2.5.6; SageN, Inc., San Jose, CA, USA) and Proteome Discoverer (software ver. 1.0; Thermo Fisher). Peptide mass tolerance was set at $5.0 \mathrm{ppm}$ and MS/MS tolerance was set internally by the software with values varying from 0 to $1 \mathrm{Da}$. Search criteria included static modifications of cysteine alkylation (57.0214 Da), modifications of lysine and N-terminals with iTAG-d0 or -d6 (113.084 or 119.118) for quantitative analyses, and variable modification of methionine by oxidation (15.9949 Da). Searches were performed with semi-tryptic digestion allowing a maximum of two missed cleavages. Peptide identifications were filtered using peptide probability $>0.9$ on the Sorcerer server using the open-source Trans-Peptide Pipeline (TPP) software (ver. 2.9.4) and false discovery rate (FDR) of $1.9 \%$ on the Proteome Discoverer using its reverse database as decoy. Peptide quantifications were analyzed using ASAPRatio software [22]. InforSense (InforSense Ltd., London, UK) ver. 4.1 for Gene Ontology (GO) annotation was used to group components, functions, and processes for proteins identified in the aforementioned experiments.

\section{Results and Discussion}

\section{Characterization of the Syk-Interacting Proteome Using GFP Nanotrap}

We first investigated the isolation efficiency of Syk-EGFP complexes using the single-chain anti-GFP antibody $\mathrm{V}_{\mathrm{H}} \mathrm{H}$, GFP nanotrap, and compared its performance to a polyclonal antibody against GFP (GFP Ab). The chicken DT40 B cells expressing Syk fused with enhanced GFP at its C-terminus (Syk-EGFP) was subsequently generated. Fluorescence microscopy of intact cells and Western blotting of cell lysates with a Syk antibody confirmed the expression of Syk-EGFP in the stably transformed DT40 cells (Figure 1A, B). Syk-EGFP was distributed in both the cytoplasmic and nuclear factions, consistent with previous reports [18]. We selected the protocols that are optimum for GFP nanotrap and GFP $A b$, respectively. Isolated proteins were separated by SDS-PAGE and probed by Western blotting with an antiSyk antibody. The relative amounts of Syk-EGFP that bound to each resin or were present in the flowthrough were compared by Western blotting (Figure 2A). These results indicated that the method using GFP nanotrap was more efficient than with the GFP $\mathrm{Ab}$ for the isolation of the GFP fusion protein. Mass spectrometric analyses of the isolated protein mixtures confirmed the WB results (Figure 3). It identified 908 unique peptides representing 358 proteins in the Syk-EGFP complexes purified using GFP nanotrap, and only 62 proteins in the complexes obtained from Sykdeficient cells. In contrast, the complexes isolated from SykEGFP-expressing cells using the GFP Ab contained 221 proteins, while the complexes isolated from Syk-deficient cells contained 237. The majority of proteins in the two GFP $\mathrm{Ab}$ complexes overlapped, suggesting that a substantial degree of nonspecific binding had occurred to the GFP Ab purification.

Several interesting Syk-interacting proteins were identified in the GFP nanotrap purified sample including several that had been described previously (Table 1; Supplementary Tables S1-S4 for full lists). Many of these were not detected successfully in the GFP Ab purified complex likely due to the excess of "background" proteins that contaminated these samples. Examples of previously identified Syk-associated proteins in other cell lines included CrkL, tubulin ( $\gamma$ and $\beta$ ), SHIP, BLNK, and Shc. To verify a subset of these interactions, we selected two candidates, $\gamma$-tubulin and CrkL, for further analysis through Western blotting. Both $\gamma$-tubulin and CrkL were verified by Western blotting as Syk interacting partners that were recovered by GFP nanotrap exclusively from Syk-EGFP-expressing cells (Figure 2B, C). In addition to previously reported Syk-interacting proteins, several interesting candidates for new interaction partners were identified using the GFP nanotrap approach, including
(A)

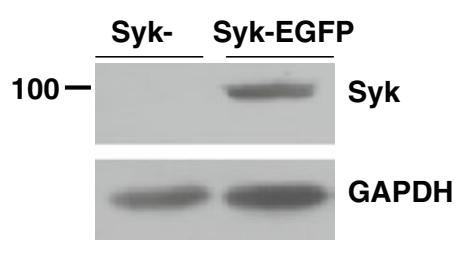

(B)

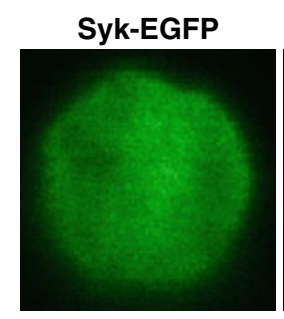

DAPI

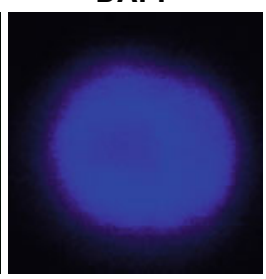

Merge

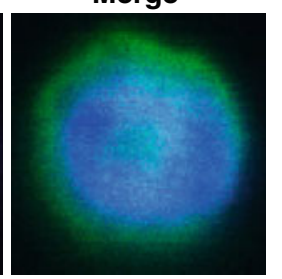

Figure 1. (A) Expression of Syk-EGFP in lysates of pools from stable DT40 B cells by Western blotting using anti-Syk antibody and anti-GAPDH (control); (B) localization of stable Syk-EGFP in DT40 B cells was examined by fluorescence microscopy 

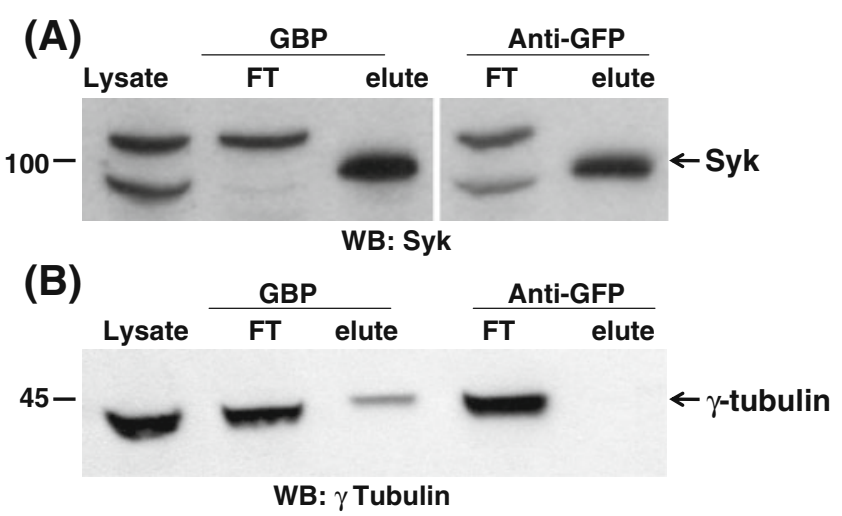

(C)
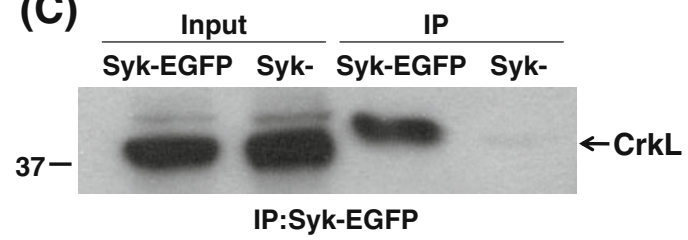

Figure 2. (A) Isolation of Syk interacting partners with antiSyk antibody and by GFP nanotrap and GFP Ab, probed by Western blot using anti-Syk antibody. (B) Isolation of $y$ tubulin in the lysate, flowthrough (FT), and elution fractions from Syk-EGFP DT40 B cells using the GFP nanotrap and GFP MAb, and analyzed by Western blotting with anti- $y-$ tubulin antibody. (C) Western blotting analysis of CrkL in the Syk-EFGP and Syk-deficient lysate and Dips using GFP nanotrap affinity purification with anti-CrkL antibody

importin 5 (IPO5)/Ran-GTP binding protein 5 (RanBP5), Exportin 5 (XPO5), Ras-GTPase-activating protein SH3domain-binding protein (G3BP1) (Table 1). The proteins identified using the GFP nanotrap from Syk-EGFP-expressing cells were analyzed using Gene ontology (GO) and grouped in terms of cellular location, molecular function, and biological process (Supplementary Figure S1). Interacting proteins were identified from multiple intracellular locations and were associated with multiple functions including protein binding (28\%), signal transduction (14\%), protein metabolism (29\%), and transport and trafficking $(9 \%)$. These functions in general correlate with biological processes in which Syk is known to be involved [14].

\section{Preparation and Characterization of $i T A G$ Reagents}

Isobaric stable isotope labeling (i.e., iTRAQ [13]) has become the major chemical labeling method for quantitative proteomics but the method has certain shortcomings, including the limitation applicable on certain types of mass spectrometers and low capacity due to the expense of the reagents. We introduce here a new reagent termed isotope Tag on Amino Groups (iTAG) for quantitative proteomics for our present study. The iTAG reagent is an active NHS ester of $N, N$ dimethyl- $\gamma$-aminobutyric acid that is prepared in either heavy or light isotopically labeled forms (Figure 4A). The reagents specifically modify peptides on primary amino groups located either at the $\mathrm{N}$ terminus or on the side chains of lysine residues, thus incorporating a tag with six hydrogen or six deuterium atoms. Similar to reductive dimethylation [23, 24], the iTAG reagents are designed to label peptides without a loss of protonation sites, which is an important factor in enhancing the ionization efficiency of peptides during MS analysis. In contrast to reductive dimethylation, the iTAG method does not use reactive sodium cyanoborohydride in the sample and the use of small amount of sodium cyanoborohydride is typically advised for optimum labeling with reductive dimethylation [25]. The coupling between amine groups and NHS-activated carboxylate is typically more efficient than reductive dimethylation [26]. More importantly, the reagents, including the heavy isotope version, are prepared by extremely simple and economic procedures and can be adapted to any biological or proteomic research group for stable isotope incorporation. The synthesis of iTAG reagents starting from $\gamma$-aminobutyric acid (GABA) is illustrated in Figure 4B. The heavy stable isotopes are incorporated into the $N, N$-dimethylated products in high yield using low-cost formaldehyde- $\mathrm{d}_{2}$ and formic acid- $\mathrm{d}_{2}$. In the second step, $N$-trifluoroacetoxy succinimide (TFA-NHS) was used to generate the active NHS esters with high efficiency.

The efficiency of labeling using iTAG and its impact on peptide ionization and quantification were first examined using peptides generated from four standard proteins, bovine serum albumin, catalase, ovalbumin, and $\beta$-lactoglobulin mixed in different ratios. These samples were digested with trypsin and the resulting peptides labeled with either light or heavy iTAG reagents. The labeled peptides were combined and analyzed by nanoflow LC-MS/MS. Peptides from all four proteins were identified and the relative levels of each protein was quantified. As shown in Table S5, the mean differences between theoretical and expected ratios for standard proteins were less than $10 \%$, which is comparable to that seen with other isotopic labeling reagents [27].

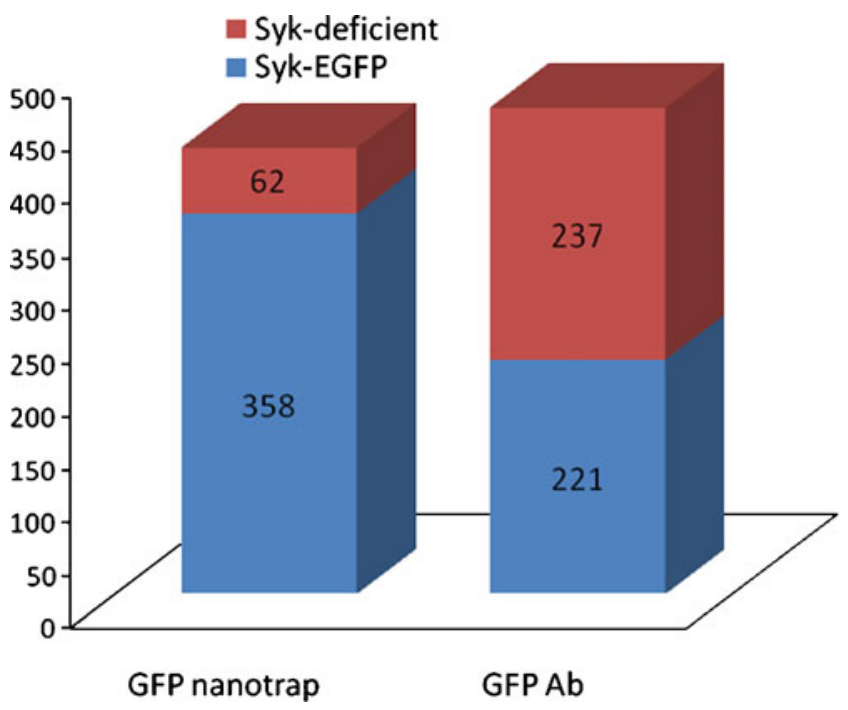

Figure 3. Proteomic comparison of GFP nanotrap and GFP Ab in DT40 Syk-EGTFP and Syk-deficient 
Table 1. Identification of potential Syk-GFP-interacting proteins by GFP nanotrap affinity purification

\begin{tabular}{|c|c|c|c|}
\hline No. & Accession no. ${ }^{\mathrm{a}}$ & Protein description from Gallus gallus & Peptide sequence \\
\hline 1 & gi|50756597 & V-crk sarcoma virus CT10 oncogene homolog (avian)-like & $\begin{array}{l}\text { TLYDFPGNDAEDLPFK } \\
\text { DSSTCPGDYVLSVSENSR } \\
\text { IHYLDTTTLIEPAPR } \\
\text { IGDQEFEHLPALLEFYK } \\
\text { IGMIPVPYVEK } \\
\text { TALALEVGDIVK } \\
\text { YPSPPMGSGSAPAMSAAEENVEYVR } \\
\text { VSHYIINSLPNR }\end{array}$ \\
\hline 2 & gi|45382211 & Src kinase,Tyrosine-protein kinase CSK (C-SRC kinase) & $\begin{array}{l}\text { HSNLVQLLGVIVEEK } \\
\text { LLYPPETGLFLVR }\end{array}$ \\
\hline 3 & gi| 57525015 & Ras-GTPase-activating protein SH3-domain-binding protein & $\begin{array}{l}\text { SPSPAPADPAPAVQEDSR } \\
\text { SEPVLEESAPEETVEK } \\
\text { YPDSHQLFVGNLPHDVDK } \\
\text { VPVSQPRPEAKPESQTPPQRPQR } \\
\text { LGSSLAGYGNVVELR } \\
\text { VPVSQPRPEAKPESQTPPQR } \\
\text { FYVHNDIFR }\end{array}$ \\
\hline 4 & gi|118088066 & Exportin 5 & $\begin{array}{l}\text { NNVMGLISSGTQSILEEESHIK } \\
\text { LFDNLLALIR } \\
\text { DPLLLAMIPK }\end{array}$ \\
\hline 5 & gi|118094808 & $\mathrm{SH} 2$ containing inositol-5-phosphatase isoform 1 & $\begin{array}{l}\text { LNQLISLLSSIEEK } \\
\text { LQYQDTSSVSDEHLK }\end{array}$ \\
\hline 6 & gi|17974316 & Protein DJ-1 (Parkinson disease protein 7 homolog) & $\begin{array}{l}\text { DVLICPDASLEDAR } \\
\text { GAEEMETVIPTDVMR }\end{array}$ \\
\hline 7 & gi| 82175533 & B cell linker protein & $\begin{array}{l}\text { TSNAVNPAKPCLPSR } \\
\text { DTFTVNEDKPTAADR }\end{array}$ \\
\hline 8 & gi|82085819 & T-complex protein 1 subunit $\theta(\mathrm{TCP}-1-\theta)$ & $\begin{array}{l}\text { ALEILPDLVCCSAK } \\
\text { DMLEAGILDTYLGK } \\
\text { LATNAAVTVLR } \\
\text { GEENLMDLQVK } \\
\text { XAVYSCPFDGMITETK } \\
\text { HYSGLEEAVYR } \\
\text { FAEAFEAIPR } \\
\text { DVDEVASLLHTSVMSK }\end{array}$ \\
\hline 9 & gi| 63173 & Cell division control protein 2 homolog (p34 protein kinase) & $\begin{array}{l}\text { LESEEEGVPSTAIR } \\
\text { IGEGTYGVVYK } \\
\text { YLDTIPSGQYLDR }\end{array}$ \\
\hline 10 & gi| 57530231 & MCM3 minichromosome maintenance deficient 3 & $\begin{array}{l}\text { TPMENIGLQDSLLSR } \\
\text { LLVNINDLR } \\
\text { QVEDDSETEKEEEEEETQPEK }\end{array}$ \\
\hline 11 & gi|118084696 & Ran_GTP binding protein 5 & $\begin{array}{l}\text { FMQDASDVMQLLLK } \\
\text { AAAAFVLANEHNIPLLK } \\
\text { LVLEQVVTSIASVADTAEEK } \\
\text { LVLEQVVTSIASVADTAEEK } \\
\text { ENVNATENCISAVGK } \\
\text { ICDIVAELAR } \\
\text { LLSSAFEEVYPALSPDDQTSLK } \\
\text { ITFLLQAIR } \\
\text { EFQQYLPVVMGPLMK } \\
\text { TKENVNATENCISAVGK } \\
\text { TKENVNATENCISAVGK } \\
\text { SLVEIADSVPK } \\
\text { LLSSAFEEVYPALSPDDQTSLK }\end{array}$ \\
\hline 12 & gi|135446 & Tubulin $\beta-1$ chain & $\begin{array}{l}\text { LTTPTYGDLNHLVSATMSGVTTCLR } \\
\text { AILVDLEPGTM }{ }^{\mathrm{D}} \text { DSR } \\
\text { GHYTEGAELVDSVLDVVR } \\
\text { EVDEQMLNVQNK } \\
\text { AILVDLEPGTMDSVR } \\
\text { SGPFGQIFRPDNFVFGQSGAGNNWAK } \\
\text { LTTPTYGDLNHLVSATMSGVTTC } \\
\text { ISEQFTAMFR } \\
\text { NSSYFVEWIPNNVK } \\
\text { LAVNMVPFPR } \\
\text { EIVHIQAGQCGNQIGAK } \\
\text { GHYTEGAELVDSVLDVVR } \\
\text { EIVHIQAGQCGNQIGAK } \\
\text { EVDEQM'LNVQNK } \\
\text { LHFFMPGFAPLTSR } \\
\text { LHFFMPGFAPLTSR } \\
\text { EVDEQMLNVQNK }\end{array}$ \\
\hline
\end{tabular}


Table 1. (continued)

\begin{tabular}{|c|c|c|c|}
\hline No. & Accession no. ${ }^{a}$ & Protein description from Gallus gallus & Peptide sequence \\
\hline $\begin{array}{l}13 \\
14 \\
15 \\
16\end{array}$ & $\begin{array}{l}\text { gi|} 228911 \\
\text { gi1 } 18102179 \\
\text { gi| } 88909244 \\
\text { gi| } 45384000\end{array}$ & $\begin{array}{l}\text { GTP-binding nuclear protein Ran (GTPase Ran) } \\
\text { Src homology collagen/adaptor protein SHC } \\
\text { Prohibitin isoform } 1 \\
\text { Nucleolin }\end{array}$ & $\begin{array}{l}\text { FPGQLNADLR } \\
\text { EIVHIQAGQCGN } \\
\text { NSSYFVEWIPNNVK } \\
\text { SLGGGTGSGMGTLLISK } \\
\text { AILVDLEPGTMDSVR } \\
\text { LAVNMVPFPR } \\
\text { QLTHSLGGGTGSGMGTLLISK } \\
\text { TEGAELVDSVLDVVR } \\
\text { VCENIPIVLCGNK } \\
\text { EAIGLVCEAVPGAK } \\
\text { NITYLPSGQSVLLQLPQ } \\
\text { TLIVNNLSYAASEETLQELFK } \\
\text { GYAFVEFPTAEDAK } \\
\text { GFGFVDSSPEAK } \\
\text { FGYVDFLSAEDMDK } \\
\text { NVFENALEVR } \\
\text { TETPASAFSLFVK } \\
\text { LEFSSPSWQK }\end{array}$ \\
\hline
\end{tabular}

a $m z$ XML file was searched against NCBI chicken protein database.

${ }^{\mathrm{b}}$ indicates methionine oxidation.

Differentially labeled peptides displayed similar chromatographic retention times with little resolution, which may due to the fact that the charged isotope tag does not have strong interaction with the stationary phase $[28,29]$. In all cases, the sequence coverage for all four proteins was greater than $70 \%$. Database searches failed to identify iTAG-labeled peptides with modifications on other residues such as cysteine, histidine, or arginine, indicating that the iTAG reagent did not participate in any detectable side reactions. These results show that the iTAG reagent provides nearly complete and quantitative labeling of amino groups from both the N-terminus and lysine side chains in standard protein samples.

We further evaluated the efficiency of labeling using the iTAG method by determining how it might affect the identification of proteins in a complex mixture. Sykinteracting proteins were isolated from Syk-EGFP-expressing DT40 cells using the GFP nanotrap procedure as described above. The purified proteins were digested with trypsin and the resulting peptides were either left unlabeled or were labeled with iTAG (d0) or iTAG (d6) and analyzed by MS/MS. The number of identified peptides labeled by iTAG (do) differed from the unlabeled peptides by only $1 \%$, while those labeled by iTAG (d6) differed from unlabeled peptides by $8 \%$ (data not shown), indicating that the iTAG labeling method did not lead to a significant loss of sample even in complex mixtures.

\section{Quantitative Analysis of Syk-Interacting Partners in DT40 Syk-EGFP-NLS and Syk-EGFP-NES Cells}

While it has been a common practice to use epitope tagged proteins for the discovery of endogenous interacting partners, the method can introduce false-positives if protein-protein interactions are formed after lysis of cells. To address this issue, we applied GFP nanotrap in a combination with iTAG to examine protein-interacting partners as a function of their intracellular locations. We therefore developed two cell lines: DT40 Syk-EGFP-NLS and DT40 Syk-EGFP-NES. In these cells, Syk-EGFP was expressed, but was confined to either the<smiles>CN(C)CCCC(=O)ON1C(=O)CCC1=O</smiles>

iTAG

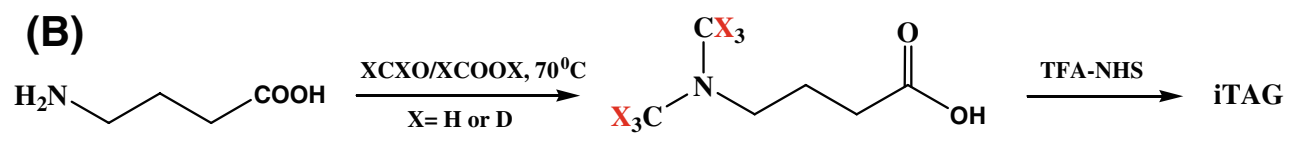

Figure 4. (A) Chemical structure of iTAG. (B) Synthetic route for ITAG reagents 
nucleus or cytoplasm, respectively, by the addition to the Cterminus of a specific localization signal sequence. The level of expression of the two Syk-EGFP fusion proteins was similar in each cell line as determined by Western blotting (data not shown). The restricted localization of the tagged kinases in each cell line was confirmed by fluorescence microscopy (Supplementary Figure S2).

The iTAG reagents were applied to label peptides differentially to compare Syk-binding proteins isolated from lysates of cells expressing Syk-EGFP-NLS or Syk-EGFPNES using the GFP nanotrap beads as described above. Syk was identified in both samples with high sequence coverage at a relative ratio of 0.91 , in consistent with the equivalent level of expression of the tagged Syk-EGFP fusion proteins in the two cell lines. We observed over 40 proteins with a minimum of two represented peptides that were present at ratios deviating significantly from 1 . For example, nucleolin (NCL) and nucleophosmin (NMP1) were quantified at relative ratios of 1.76 and 1.73 , respectively. While both proteins can shuttle between the cytoplasm and the nucleus, they are found primarily in the nucleus. Thus, their selective association with the nuclear localized form of the kinase may reflect their close proximity within the cell prior to lysis. We also observed proteins with the large difference in abundance in the two immune complexes, including the redox sensitive chaperone, DJ-1, which was present at a level 16-fold higher in the Syk-EGFP-NLS complexes, but their relationship with Syk is largely unknown.

A majority of the detected peptides had a ratio close to 1 (Table 2 and a full list in Table S6-S7) and there are three possibilities for the ratio of 1 : these proteins were either derived
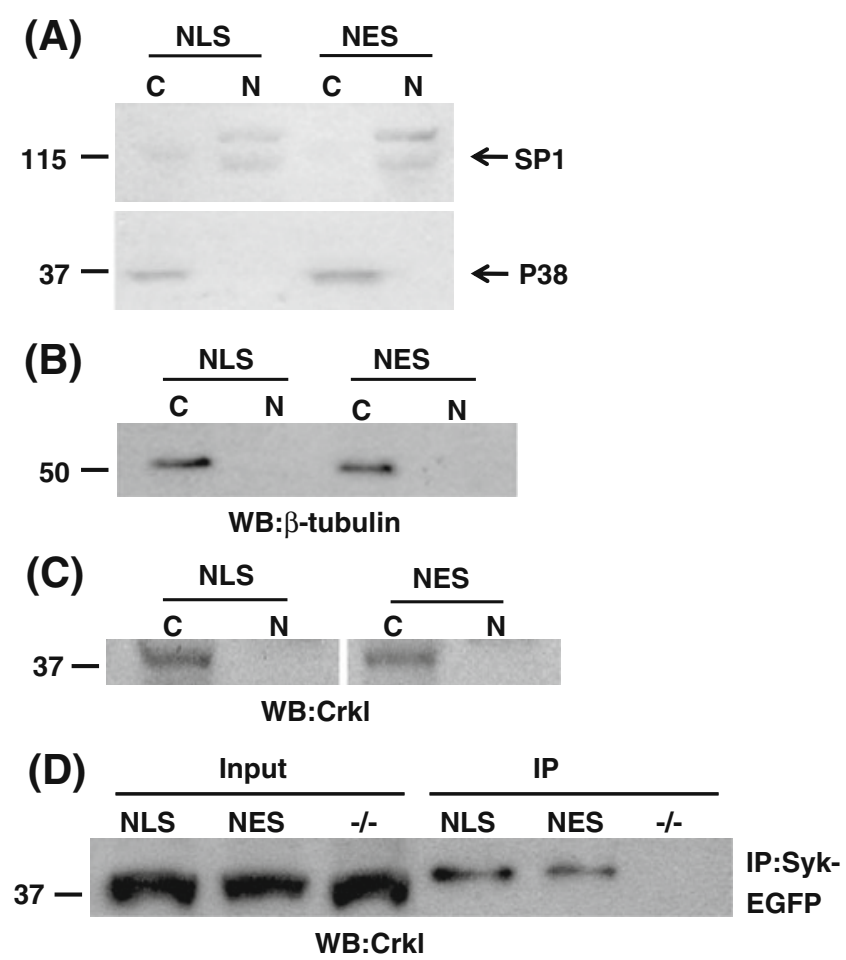

Figure 5. Cytosolic and nuclear fractionation of Syk-EFGPNLS and Syk-NES DT40 B cells. (A) Fractionation and Western blot of nuclear and cytosolic markers (SP1 and p38) in Syk-EGFP DT40 B cells, (B) Western blot confirmation of $\mathrm{y}$-tubulin in the cytosol, (C) Western blot confirmation of CrkL in the cytosol, (D) iTAG validation of 1:1 ratio of CrkL in Syk-EGFP-NLS and Syk-EGFP-NES DT40 B cells

Table 2. Identification and quantification of Syk-GFP-interacting proteins in DT40 NLS (d0) and NES (d6) B cells

\begin{tabular}{|c|c|c|c|}
\hline No. & Accession $^{\mathrm{a}}$ & Protein description from Gallus gallus & ratio mean \pm stdev $^{b}$ \\
\hline 1 & gi|104829 & Ubiquitin precursor & $1.27 \pm 0.09$ \\
\hline 2 & gi|1172839 & GTP-binding nuclear protein Ran (GTPase Ran) & $1.19 \pm 0.41$ \\
\hline 3 & gi|1703321 & Annexin A6 & $0.64 \pm 0.03$ \\
\hline 4 & gi|212258 & macrophage migration inhibitory factor & $1.26 \pm 0.03$ \\
\hline 5 & gi|3420726 & Rab-GDP dissociation inhibitor & $1.47 \pm 0.11$ \\
\hline 6 & gi|46048903 & voltage-dependent anion channel 2 & $0.79 \pm 0.28$ \\
\hline 7 & gi|53127883 & MCM2 minichromosome maintenance deficient 2 & $0.94 \pm 0.56$ \\
\hline 8 & gi|53130462 & serine/threonine kinase receptor associated protein & $0.29 \pm 0.17$ \\
\hline 9 & gi $\mid 53130808$ & MCM5 minichromosome maintenance deficient 5 & $1.72 \pm 0.15$ \\
\hline 10 & gi| 53136380 & RuvB-like 1 & $1.25 \pm 0.22$ \\
\hline 11 & gi|60098769 & SET translocation (myeloid leukemia-associated) & $1.41 \pm 0.10$ \\
\hline 12 & gi 10178878 & eukaryote initiation factor 2 beta & $1.33 \pm 0.28$ \\
\hline 13 & gi|118094464 & natural killer cell enhancing factor isoform 1 & $1.26 \pm 0.14$ \\
\hline 14 & gi|118084696 & Ran-GTP binding protein 5 & $1.50 \pm 0.07$ \\
\hline 15 & gi|118102312 & Importin 9 & $2.85 \pm 0.53$ \\
\hline 16 & gi|118096008 & Acidic leucine-rich nuclear phosphoprotein 32 family member A (leucine-rich acidic nuclear protein) & $0.80 \pm 0.35$ \\
\hline 17 & gi|135393 & Tubulin $\beta-7$ chain & $1.13 \pm 0.01$ \\
\hline 18 & gi| 1172808 & Ribosomal protein L10 (Jun-binding protein) & $1.95 \pm 0.03$ \\
\hline 19 & gi|50756597 & V-crk sarcoma virus CT10 oncogene homolog (avian)-like & $0.98 \pm 0.07$ \\
\hline 20 & gi| 17974316 & DJ-1 & $16.0 \pm 1.42$ \\
\hline 21 & gi|45384000 & Nucleolin & $1.76 \pm 0.27$ \\
\hline 22 & gi $\mid 128413$ & Nucleophosmin & $1.73 \pm 0.17$ \\
\hline
\end{tabular}

a $m z$ XML file was searched against NCBI chicken protein database.

${ }^{b}$ The ratios of isotopic pairs were calculated using ASRPatio software. 
from Syk-EGFP-associated proteins that were distributed throughout the cell, associated with the Syk-EGFP fusion proteins during or following cell lysis, or arose from contaminants present equally in the two complexes. To take a closer look at these proteins, we used CrkL as one example. CrkL was identified in Figure 2 as a specific Syk-associated protein. CrkL is a member of the Crk-family of adaptor proteins [30] that has been reported to associate with Syk in platelets via its $\mathrm{SH} 2$ and $\mathrm{SH} 3$ domains and with the Syk-family kinase Zap-70 in T cells [31]. We have also observed an interaction between Syk and Crk in a yeast two-hybrid screen (Q. Zhou and R. L. Geahlen, unpublished observations), further supporting a direct interaction between proteins of these two families). To closely examine its location in the DT40 cells, we fractionated DT40 Syk-EGFP-NLS and SykEGFP-NES cells into nuclear and cytosolic fractions and verified the separation by Western blotting using antibodies against SP1 and p38 as markers of the nuclear and cytoplasmic fractions, respectively (Figure 5A). Western blotting with antibodies against $\mathrm{CrkL}$ indicated that the protein was present specifically in the cytoplasmic fraction (Figure 5B, C). In contrast, approximately equal amounts of CrkL were recovered in GFP nanotrap complexes prepared from whole cell extracts of DT40 Syk-EGFP-NLS and Syk-EGFP-NES cells by WB analysis (Figure 5D) and iTAG labeling (Table 2). These experiments confirmed that CrkL is a Syk-interacting protein, and its intracellular interaction with Syk mainly remains in the cytoplasm. Therefore, our measurement of the ratio of close to 1 for CrkL is most likely due to the post-lysis condition that led to in vitro interaction between CrkL and Syk. Similar cases also apply to BLNK/SLP65, a Syk substrate, binding partner and scaffolding protein critical for signaling through the B cell antigen receptor [32, 33], Shc, a guanine nucleotide exchange factor for Ras and a binding partner and substrate of Syk in B cells [34], and the SH2 domain-containing inositol 5-phosphatase, SHIP, reported previously to bind to Syk in B cells and macrophages [35]. Similarly, $\beta$-tubulin was localized selectively to the cytoplasm, but also was found in a nearly $1: 1$ ratio in the two immune complexes. A number of peptides from high abundance proteins also were present at 1:1 ratios and many of these likely resulted from post-lysis false-positive interactions. To further confirm our observation, we fractionated DT40 SykEGFP-NLS and Syk-EGFP-NES cells into nuclear and cytosolic fractions and then isolated the Syk-interacting complex by GFP nanotrap. Proteins were identified by mass spectrometry (Supplementary Table S8, S9). The data confirmed that a number of proteins, including CrkL, which were originally quantified in $1: 1$, actually exist in either nucleus or cytoplasm exclusively. We conclude, therefore, that mixing of cellular components during cell lysis likely allowed for the identification of a subset of interactions that did not reflect the restricted subcellular localization of the target proteins.

In summary, in the present study we examined the utility of GFP nanotrap in the isolation of a tyrosine kinase complex, resulting in more proteins being identified with fewer contaminating proteins compared to the GFP $\mathrm{Ab}$ method. Furthermore, we introduced a new and costeffective stable isotopic labeling reagent, iTAG. While the preparation of NHS esters is typically achieved by treating carboxylic acids with NHS in the presence of $N, N^{\prime}-$ dicyclohexylcarbodiimide or 1-ethyl-3-(3-dimethylaminopropyl) carbodiimide and requires lengthy column chromatography for the purification of the reaction products, the use of TFA-NHS to synthesize NHS esters is efficient and convenient and the final product can be obtained in high purity with a simple recrystallization step. Secondly, similar to other reagents that label through amine groups, iTAG reagents label virtually every peptide from proteolyzed proteins, allowing quantitative analyses to be performed with high protein sequence coverage. Finally, the conversion of amino groups to more basic dimethylamino groups slightly increases the overall efficiency of peptide ionization. The specificity and efficiency of the iTAG reagents were examined with standard proteins and complex mixture. Combining GFP nanotrap with iTAG, we identified and quantified over 200 interacting proteins in Syk-EGFP-NLS and Syk-EGFP-NES cells. These fell into several categories including proteins present at a 1:1 ratio that represented high abundance proteins that likely were contaminates in the immune complexes as well as proteins that are known to be specific binding partners of Syk. The identification of associated proteins often is based on the assumption that protein complexes can be isolated while preserving preexisting protein-protein interactions during lysis and purification. However, the finding of $\mathrm{CrkL}$ and other proteins at a nearly $1: 1$ ratio despite their concentration in the cytoplasmic fraction suggests that some interactions can and do occur following cell lysis. Our study suggests that extra caution should be taken in evaluating the results obtained by affinity purification strategies.

\section{Acknowledgments}

The authors acknowledge that this project was funded in part by an NSF CAREER award (W.A.T.) and National Institutes of Health grants RR025802 (W.A.T.), CA115465 (R.L.G. and W.A.T.), and CA037372 (R.L.G.). They thank Dr. H. Leonhardt and Dr. U. Rothbauer from Ludwig Maximilians University for the initial supply of GFP nanotrap reagent.

\section{References}

1. Gingras, A.C., Gstaiger, M., Raught, B., Aebersold, R.: Analysis of protein complexes using mass spectrometry. Nat Rev Mol Cell Biol 8 (8), 645-654 (2007)

2. Wang, X., Huang, L.: Identifying dynamic interactors of protein complexes by quantitative mass spectrometry. Mol Cell Proteomics 7 (1), 46-57 (2008)

3. Akiyoshi, B., Nelson, C.R., Ranish, J.A., Biggins, S.: Quantitative proteomic analysis of purified yeast kinetochores identifies a PP1 regulatory subunit. Genes Dev 23(24), 2887-2899 (2009)

4. Xu, P., Duong, D.M., Seyfried, N.T., Cheng, D., Xie, Y., Robert, J., Rush, J., Hochstrasser, M., Finley, D., Peng, J.: Quantitative proteomics reveals the function of unconventional ubiquitin chains in proteasomal degradation. Cell 137(1), 133-145 (2009) 
5. Rothbauer, U., Zolghadr, K., Tillib, S., Nowak, D., Schermelleh, L., Gahl, A., Backmann, N., Conrath, K., Muyldermans, S., Cardoso, M.C., Leonhardt, H.: Targeting and tracing antigens in live cells with fluorescent nanobodies. Nat Methods 3(11), 887-889 (2006)

6. Rothbauer, U., Zolghadr, K., Muyldermans, S., Schepers, A., Cardoso, M.C., Leonhardt, H.: A versatile nanotrap for biochemical and functional studies with fluorescent fusion proteins. Mol Cell Proteom 7(2), 282-289 (2008)

7. Trinkle-Mulcahy, L., Boulon, S., Lam, Y.W., Urcia, R., Boisvert, F.M., Vandermoere, F., Morrice, N.A., Swift, S., Rothbauer, U., Leonhardt, H., Lamond, A.: Identifying specific protein interaction partners using quantitative mass spectrometry and bead proteomes. J Cell Biol 183(2), 223-239 (2008)

8. Ranish, J.A., Yi, E.C., Leslie, D.M., Purvine, S.O., Goodlett, D.R., Eng, J., Aebersold, R.: The study of macromolecular complexes by quantitative proteomics. Nat Genet 33(3), 349-355 (2003)

9. Blagoev, B., Kratchmarova, I., Ong, S.E., Nielsen, M., Foster, L.J., Mann, M.: A proteomics strategy to elucidate functional protein-protein interactions applied to EGF signaling. Nat Biotechnol 21(3), 315-318 (2003)

10. Chen, X., Andrews, P.C.: Quantitative proteomics analysis of pancreatic zymogen granule membrane proteins. Methods Mol. Biol. (Clifton, N.J.) 528, 327-338 (2009)

11. Ong, S.E., Blagoev, B., Kratchmarova, I., Kristensen, D.B., Steen, H., Pandey, A., Mann, M.: Stable isotope labeling by amino acids in cell culture, SILAC, as a simple and accurate approach to expression proteomics. Mol Cell Proteom 1(5), 376-386 (2002)

12. Gygi, S.P., Rist, B., Gerber, S.A., Turecek, F., Gelb, M.H., Aebersold, R.: Quantitative analysis of complex protein mixtures using isotopecoded affinity tags. Nat Biotechnol 17(10), 994-999 (1999)

13. Ross, P.L., Huang, Y.N., Marchese, J.N., Williamson, B., Parker, K., Hattan, S., Khainovski, N., Pillai, S., Dey, S., Daniels, S., Purkayastha, S., Juhasz, P., Martin, S., Bartlet-Jones, M., He, F., Jacobson, A., Pappin, D.J.: Multiplexed protein quantitation in Saccharomyces cerevisiae using amine-reactive isobaric tagging reagents. Mol Cell Proteom 3(12), 1154-1169 (2004)

14. Geahlen, R.: L.; Syk and pTyr'd: signaling through the B cell antigen receptor. Biochim Biophys Acta 1793(7), 1115-1127 (2009)

15. Sada, K., Takano, T., Yanagi, S., Yamamura, H.: Structure and function of Syk protein-tyrosine kinase. J Biochem 130(2), 177-186 (2001)

16. Ma, H., Yankee, T.M., Hu, J., Asai, D.J., Harrison, M.L., Geahlen, R.L.: Visualization of Syk-Antigen receptor interactions using green fluorescent protein: differential roles for Syk and Lyn in the regulation of receptor capping and internalization. J Immunol 166(3), 1507-1516 (2001)

17. Takata, M., Sabe, H., Hata, A., Inazu, T., Homma, Y., Nukada, T. Yamamura, H., Kurosaki, T.: Tyrosine kinases Lyn and Syk regulate B cell receptor-Coupled $\mathrm{Ca} 2+$ mobilization through distinct pathways. EMBO J 13(6), 1341-1349 (1994)

18. Zhou, F., Hu, J., Ma, H., Harrison, M.L., Geahlen, R.L.: Nucleocytoplasmic trafficking of the Syk protein tyrosine kinase. Mol Cell Biol 26 (9), 3478-3491 (2006)

19. Rao, T.S., Nampalli, S., Sekher, P., Kumar, S.: TFA-NHS as bifunctional protecting agent: simultaneous protection and activation of amino carboxylic acids. Tetrahedron Lett 43(43), 7793-7795 (2002)
20. Ficarro, S.B., Zhang, Y., Lu, Y., Moghimi, A.R., Askenazi, M., Hyatt, E., Smith, E.D., Boyer, L., Schlaeger, T.M., Luckey, C.J., Marto, J.A.: Improved electrospray ionization efficiency compensates for diminished chromatographic resolution and enables proteomics analysis of tyrosine signaling in embryonic sstem cells. Anal Chem 81(9), 3440-3447 (2009)

21. Link, A.J., Eng, J., Schieltz, D.M., Carmack, E., Mize, G.J., Morris, D. R., Garvik, B.M., Yates JR 3rd.: Direct analysis of protein complexes using mass spectrometry. Nat. Biotechnol. 17(7), 676-682 (1999)

22. Li, X., Zhang, H., Ranish, J.A., Aebersold, R.: Automated statistical analysis of protein abundance ratios from data generated by stableisotope dilution and tandem mass spectrometry. Anal Chem 75(23), 6648-6657 (2003)

23. Hsu, J.L., Huang, S.Y., Shiea, J.T., Huang, W.Y., Chen, S.H.: Beyond quantitative proteomics: signal enhancement of the a1 ion as a mass tag for peptide sequencing using dimethyl labeling. J Proteome Res 4(1), 101-108 (2005)

24. Fu, Q., Li, L.: De novo sequencing of neuropeptides using reductive isotopic methylation and investigation of ESI QTOF MS/MS fragmentation pattern of neuropeptides with N-terminal dimethylation. Anal Chem 77(23), 7783-7795 (2005)

25. Guo, K., Ji, C., Li, L.: Stable-isotope dimethylation labeling combined with LC-ESI MS for quantification of amine-containing metabolites in biological samples. Anal Chem 79(22), 8631-8638 (2007)

26. Boersema, P.J., Raijmakers, R., Lemeer, S., Mohammed, S., Heck, A.J.: Multiplex peptide stable isotope dimethyl labeling for quantitative proteomics. Nat Protoc 4(4), 484-494 (2009)

27. Gygi, S.P., Rist, B., Gerber, S.A., Turecek, F., Gelb, M.H., Aebersold, R.: Quantitative analysis of complex protein mixtures using isotopecoded affinity tags. Nat Biotechnol 17(10), 994-999 (1999)

28. Zhang, R., Regnier, F.E.: Minimizing resolution of isotopically coded peptides in comparative proteomics. J Proteome Res 1(2), 139-147 (2002)

29. Zhang, R., Sioma, C.S., Thompson, R.A., Xiong, L., Regnier, F.E.: Controlling deuterium isotope effects in comparative proteomics. Anal Chem 74(15), 3662-3669 (2002)

30. Feller, S.M.: Crk, family adaptors-signaling complex formation and biological roles. Oncogene 20(44), 6348-6371 (2001)

31. Gelkop, S., Isakov, N.: T cell activation stimulates the association of enzymatically active tyrosine-phosphorylated ZAP-70 with the Crk adapter proteins. J Biol Chem 274(31), 21519-21527 (1999)

32. Abudula, A., Grabbe, A., Brechmann, M., Polaschegg, C., Herrmann, N., Goldbeck, I., Dittmann, K., Wienands, J.: SLP-65 signal transduction requires Src homology 2 domain-mediated membrane anchoring and a kinase-independent adaptor function of Syk. J Biol Chem $\mathbf{2 8 2}$ (39), 29059-29066 (2007)

33. Kulathu, Y., Hobeika, E., Turchinovich, G., Reth, M.: The kinase Syk as an adaptor controlling sustained calcium signaling and B-cell development. EMBO J 27(9), 1333-1344 (2008)

34. Nagai, K., Takata, M., Yamamura, H., Kurosaki, T.: Tyrosine phosphorylation of She is mediated through Lyn and Syk in B cell receptor signaling. J Biol Chem 270(12), 6824-6829 (1995)

35. Crowley, M.T., Harmer, S.L., DeFranco, A.L.: Activation-induced association of a 145-kDa tyrosine-phosphorylated protein with Shc and Syk in B lymphocytes and macrophages. J Biol Chem 271(2), 1145-1152 (1996) 